\title{
Growth and yield attributes of wheat crop in response to application of micronutrients: A review
}

\section{Ganpat Louhar}

Division of Soil Science and Agricultural Chemistry, Indian Agricultural Research Institute (IARI), New Delhi-110012, India

E-mail: loharganpat95@gmail.com

\begin{abstract}
Wheat is one of the most important cereal crop and staple foods in the world. Increase in productivity of wheat by balance nutrient management is one of the most crucial factors. The main objective this study is to assessing the role of micronutrients in improving different components of wheat yield. There are different methods of application such as seed priming, soil application and fortification but foliar application is more beneficial. This is due to response of foliar application has positive and quadrate in nature i.e. the optimum dose of foliar application of zinc for grain yield of wheat was observed as $0.04 \%$. Among treatments of micronutrient alone or combined forms give better results over control. Results have show that micronutrient application substantially improved leaf area index (LAI), leaf area duration, CGR (Crop growth rate), RGR (Relative growth rate), NAR (Net assimilation rate), plant height, spike length, spikelets/spike, grains/spike, test weight, tillers $\mathrm{m}^{-2}$, grain yield, chlorophyll content and biological yield as well as harvest index of wheat. The yield and quality of wheat products improved and boosted by micronutrient applications. Therefore, human and animal health will be protected with the feed of enriched and balanced nutrition of produce as well as it will help in facing the severe global food security.
\end{abstract}

Keywords: Crop growth rate, Leaf area index, Micronutrient, Net assimilation rate, Relative growth rate

\section{INTRODUCTION}

Wheat (Triticum aestivum L.) is one of the most important cereal crops which provide staple food to many countries in the world. Deficiency of micronutrients such as iron (Fe), manganese $(\mathrm{Mn})$, copper $(\mathrm{Cu})$, zinc $(\mathrm{Zn})$, boron $(\mathrm{B})$, molybdenum (Mo) increased in crops worldwide in recent years. Many factors which causes deficiency problems are intensification in cropping system, chemical fertilizers (NPK), over liming of acid soils, and the increased demand of high-yielding varieties to feed the global population (Fageria et al., 2007). A balanced fertilization of macronutrients with micronutrients for plant nutrition is very important for high yield crops and good quality products. Micronutrients play a vital role in chlorophyll synthesis and formation, nucleic acid, protein synthesis, enzymatic activities, photosynthesis as well as respiration (Reddy, 2004).

The balance use of macronutrients and micronutrients is vital role in crop nutrition for improved yield and quality (Saeed et. al, 2012). High fertilizer responsive cultivars having potential to more crop yield, when applied micronutrients with NPK fertilizers (Nataraja et al., 2006). Leiw (1988) has observed that there is an increase in crop production due to application of micronutrients. There are different methods to apply the micronutrients such as seed priming, soil application and fortification but foliar application is more beneficial. Bameri et al. (2012) stated that by spraying micronutrients root growth in wheat can be improved which increase in uptake of macro and micronutrients. Ziaeian and Malakouti (2001) observed that fertilization of $\mathrm{Fe}, \mathrm{Mn}, \mathrm{Zn}$ and $\mathrm{Cu}$ significantly increased grain and straw yield, test weight, and the number of grains per spikelet. Also found that application of $\mathrm{Fe}$ will increased the concentration and total uptake of $\mathrm{Fe}$ in grain, flag leaves, and grain protein contents.

Among the micronutrients, especially $\mathrm{Zn}$ and $\mathrm{Fe}$ reduce the susceptibility of plants to drought stress (Sultana et al., 2001; Khan et al., 2003; Cakmak, 2008). Asad and Rafique (2002) showed that increased in wheat dry matter, grain yield, and straw yield significantly by application micronutrients over an unfertilized control. Khan et al., (2010) observed that when micronutrients (Fe, $\mathrm{Mn}, \mathrm{Zn}, \mathrm{Cu}$ and B) applied at different growth stages of wheat by foliar application significantly increased the plants height, grains per spike, test 
weight, biological yield, harvest index, straw and grain yield etc. Ali (2012) showed that foliar application of $\mathrm{Fe}$ at different growth stages increased the plant height, spike length, 1000-grain weight, grain weight per spike, grain yield, grain protein content and protein yield of wheat over a control treatment. Chaudry et al. (2007) found that micronutrients $(\mathrm{Zn}, \mathrm{Fe}, \mathrm{B})$ positively increased the wheat yield over control while Mandal et al. (2007) found that positive interaction between fertilizer treatments and physiological stages of wheat growth. Rehm and Albert (2006) found that the Fe -chlorosis in wheat can be corrected by foliar spray of ferrous sulphate.

Rawashdeh and Sala (2013) observed that combined foliar application of mixture nutrients $\mathrm{Fe}$ and $B$ also increased plant height, number of tillers and root depth than control treatment. Gomaa et al., (2015) showed that the highest grain and yield components and quality of wheat grain obtained by foliar application of both $\mathrm{Zn}$ and Fe. Ali et al., in 2009 and Moghadam et al., in 2012 found that foliar application of $\mathrm{B}$ and $\mathrm{Zn}$ increased the yield and yield components of wheat. Foliar application of $B$ was positive effect on grain yield, number of grains per spike and 1000-grain weight Raza et al. (2014).

The main objective of this study was to identify the micronutrients deficiencies, factors responsible for fertilizer efficiency improvement under the agroecology of the wheat area as well as required adequate amount of micronutrients to achieve maximum yields and suggested diagnostic criteria for identification of crop responsive to micronutrients.

Growth and yield attributes of wheat

Leaf area index (LAI) at 49 and 98 days after sowing: The LAI is the ratio of total leaf area to ground cover. In general it increases to maximum after the crop emergence (Reddy, 2004). Application of boron in wheat will increases the tissue formation with good plant growth which increases the concentration of $B$ in wheat leaves and results in higher leaf area index. Whereas, when combined application of $B$ with zinc, copper, iron and manganese, it helps in chlorophyll formation and increased the photosynthetic activities (Ziaeian and Malakouti, 2001; Card et al., 2005; Manal et al., 2010). The application of iron (12 kg ha-1) and copper $\left(6 \mathrm{~kg} \mathrm{ha}^{-1}\right)$ produced the minimum leaf area index of 2.31 and 2.38, respectively.

Leaf area duration (LAD) at 49 and 98 days after sowing: Leaf area duration is directly related with leaf area index. Nadim et al. (2011) observed that non significant effect on LAD at 49 DAS and significant effect on LAD 98 DAS in wheat. The application of boron @ $2 \mathrm{~kg} \mathrm{ha}^{-1}$ gives maximum LAD (48.90) and it was statistically similar to combined $\mathrm{Zn}+\mathrm{Cu}+\mathrm{Fe}+\mathrm{Mn}+\mathrm{B}$ with $\mathrm{LAD}$ 47.25.

Crop growth rate $\left(\mathrm{g} \mathrm{m}^{-2}\right.$ day $\left.^{-1}\right)$ : Crop growth rate
(CGR), defined as the dry matter production per unit time. It is affected by several factors such as temperature, solar radiation and age of cultivar. Nadim et al. (2011) observed that application of micronutrients improved the plant growth of wheat through increased plant photosynthesis and other physiological activities. When applied boron @ 2 $\mathrm{kg} \mathrm{ha}^{-1}$ improved the crop growth rate $\left(33.40 \mathrm{~g} \mathrm{~m}^{-2}\right.$ day $\left.^{-1}\right)$. The combined application of micronutrients $(\mathrm{Zn}+\mathrm{Cu}+\mathrm{Fe}+\mathrm{Mn}+\mathrm{B})$ and sole application of zinc and copper gives CGR of 28.08, $27.44 \mathrm{~g} \mathrm{~m}^{-2}$ day $^{-1}$, respectively. This is due to boron helps in better utilization of available nutrients which increased leaf area, high photosynthesis and dry matter accumulation. Asad and Rafique (2002) reported that use of medium doses of boron or zinc and/or iron enhances higher CGR of wheat whereas low amount of copper, manganese and combination of all micronutrients application gives higher CGR.

Relative growth rate $\left(\mathrm{mg} \mathrm{m}^{-1}\right.$ day $\left.^{-1}\right)$ : Relative growth rate (RGR) refers to the increase in dry weight with time related to the initial weight. So CGR is an absolute measure of growth, similar values could be expected for different initial weights (Reddy, 2004). Nadim et al. (2011) revealed that application of boron $\left(3 \mathrm{~kg} \mathrm{ha}^{-1}\right)$ in wheat gives significantly maximum RGR (89.60), which was statistically at par $(88.73,88.45$ and $87.38 \mathrm{mg} \mathrm{m}^{-1}$ day $^{-1}$ ) with the sole application of $\mathrm{Cu}$ $\left(6 \mathrm{~kg} \mathrm{ha}^{-1}\right), \mathrm{Zn}\left(10 \mathrm{~kg} \mathrm{ha}^{-1}\right)$ and Fe (12 kg ha-1), respectively. The reason behind the high concentrations of $B$ and $Z n$ in the leaves increased plant food accumulation which resulted in more RGR (Card et al., 2005; Nataraja et al., 2006). Kumar et al. (2009) also revealed that high dose of copper increased the $\mathrm{Cu}$ concentrations in wheat leaves and dry matter production. As compared to its sole application, combined application of boron gives good relative growth rate.

Net assimilation rate $\left(\mathrm{mg} \mathrm{m}^{-2}\right.$ day $\left.^{-1}\right)$ : The capacity of plant to increase dry weight in terms of area of its assimilatory surface termed as the net assimilation rate (NAR). Generally it is photosynthetic efficiency in the overall sense and related with LAR and RGR (Reddy, 2004). Among various treatments, the application of copper @ 6 kg ha ${ }^{-1}$ in wheat produced maximum net assimilation rate (3.19) which was statistically at par with the application of zinc $\left(2.92 \mathrm{mg} \mathrm{m}^{-2}\right.$ day $\left.^{-1}\right)$. This is due to high concentrations of $\mathrm{Cu}$ in the wheat leaves and more RGR resulted increased in photosynthetic rate and chlorophyll formation. Shukla and Warsi (2000) also found that the highest NAR with the application of $\mathrm{Zn}$ alongside with NPK.

Number of tillers $\left(\mathrm{m}^{-2}\right)$ : Tillering capacity of crop generally depends on the genotype and environment. Zain et al. (2015) reported that combined application of $\left(\mathrm{FeSO}_{4}+\mathrm{ZnSO}_{4}+\mathrm{MnSO}_{4}\right)$ produced maximum number of tillers (292.33) followed by $\left(\mathrm{FeSO}_{4}+\mathrm{ZnSO}_{4}\right)$ and $(3 \mathrm{Kg} \mathrm{ZnSO})$ while $\left(\mathrm{FeSO}_{4}\right.$ 
$+\mathrm{MnSO}_{4}$ ) treatment gives minimum tillers. Islam et al. (1999) suggested that zinc application improved wheat spike length and productive tillers/ plant. Among various treatments, $\mathrm{Cu}\left(8 \mathrm{~kg} \mathrm{ha}^{-1}\right)$ gives maximum number of tillers (249.0), followed by sole application of Mn, Cu, Zn and Mn @ 8, 6, 10 and $16 \mathrm{~kg} \mathrm{ha}^{-1}$ produced similar number of tillers $\left(229.8,226.5,220.8\right.$ and $\left.218.5 \mathrm{~m}^{-2}\right)$, respectively. Kumar et al. (2009) also found that increased number of tillers with the application of $\mathrm{Cu}$ in wheat while Manal et al. (2010) obtained higher number of tillers with the application of $\mathrm{Mn}$. Number of grains (spike ${ }^{-1}$ ): Number of grains spike $^{-1}$ mainly affected by unbalanced nutrition. Application of micronutrients combined with basal dose of NPK significantly improved the number of grains spike ${ }^{-1}$ in wheat. Modaihsh (1997) repoted that $\mathrm{Zn}$ application can increased the grain yield as well as biological yield of wheat. biomass. The application boron $\left(2 \mathrm{~kg} \mathrm{ha}^{-1}\right)$ gives maximum number of grains (46.50) which were statistically at par with $\mathrm{Zn}+\mathrm{Cu}+\mathrm{Fe}+\mathrm{Mn}+\mathrm{B}$ (45.25). Because of boron is helps in translocation of food materials, grain setting as well as higher number of grains in wheat. Uddin et al. (2008) also obtained higher number of grains by the application of boron $(2 \mathrm{~kg}$ $\mathrm{ha}^{-1}$ ) while Tahir et al. (2009) showed that substantially increase in number of wheat grains with the foliar application of boron. The application of $\mathrm{Zn}, \mathrm{Fe}$ and $\mathrm{Mn} @$ 5, 16 and $12 \mathrm{~kg} \mathrm{ha}^{-1}$ gives statistically similar results (44.25). whereas the combined application of medium doses of micronutrients and sole application of B and Cu @ 3 and 10 $\mathrm{kg} \mathrm{ha}^{-1}$ obtained same number of grains spike ${ }^{-1}$ (43.50, 43.25 and 43.00).

Spike length (cm): Zain et al. (2015) showed that spike length significantly increased by foliar application of micronutrients. Maximum spike length $(10.97 \mathrm{~cm})$ was observed in wheat by $(\mathrm{FeSO} 4+$ ZnSO4) which treatment was statistically similar to $(\mathrm{ZnSO} 4+\mathrm{MnSO} 4)$, and (1.6 kg FeSO4), whereas minimum spike length $(8.733 \mathrm{~cm})$ was observed in (3 kg ZnSO4) treatment which was similar to (1 kg MnSO4) treatment. According to Abbas et al. (2009) spike length of wheat can be increase up to $11.8 \%$ by application of $\mathrm{Zn} @ 10 \mathrm{~kg} \mathrm{ha}^{-1}$. Also Blevins and Lukaszewki (1998) revealed that spike length of wheat may increased by balanced availability of nutrients in the rhizosphere, their uptake and absorption by the plant.

1000 grain weight $(\mathrm{g})$ : The combined application of $(\mathrm{Zn}+\mathrm{Cu}+\mathrm{Fe}+\mathrm{Mn}+\mathrm{B})$ gives significant maximum wheat grain weight $(44.64 \mathrm{~g})$ which was statistically at par $(44.02 \mathrm{~g})$ with grain weight obtained by $\mathrm{Cu}$ and $\mathrm{Fe} @ 10$ and $12 \mathrm{~kg} \mathrm{ha}^{-1}$ respectively. This may be due to higher accumulation of assimilates in the grains, which resulted in heavier grains of wheat. Soleimani (2006) also observed increased in seeds weight by combined application of $\mathrm{Zn}$, $\mathrm{Fe}, \mathrm{Mn}$ and $\mathrm{Cu}$.
Grain yield ( $\mathbf{t ~ h a}^{-1}$ ): The conversion of light energy into chemical energy by green plants through the process of photosynthesis results rate at which a crop accumulates organic matter termed as crop productivity (Reddy, 2004). The grain yield depends on number of spikes, kernels spike- ${ }^{1}$ and kernels weight. Attributes such as (test weight) 1000 -grain weight, grain and straw yield can be increased due to micronutrient application suggested by Ziaeian and Malakouti (2001) and Maralian (2009). Sultana et al. (2016) observed that highest grain yield of wheat $\left(5.14 \mathrm{t} \mathrm{ha}^{-1}\right)$ obtained due to application of zinc up to $0.04 \%$. Kaya and Higgs (2002) and Cakmak (2008) also onserved that zinc increased the production of biomass. This is due to $\mathrm{Zn}$ will be detoxifies the Reactive Oxygen Species (ROS) and results it preventing photoxidative damage catalyzed by ROS in chloroplasts (Cakmak, 2000; Ducic and Polle, 2005). Zn play role in drought stress tolerance by protection against oxidative damage of membranes (Cakmak, 2000; Ducic and Polle, 2005). Khan et al. (2007) also reported that by application of $\mathrm{Zn}\left(5 \mathrm{~kg} \mathrm{ha}^{-1}\right.$ grains yield increases up to $31.6 \%$ over control. Among various treatments, $\mathrm{B}\left(2 \mathrm{~kg} \mathrm{ha}^{-1}\right)$ produced maximum grain yield $\left(3.67 \mathrm{t} \mathrm{ha}^{-1}\right)$ whereas $\mathrm{Cu}$ and Mn both @8 kg ha ${ }^{-1}$ was statistically at par with boron producing grain yield of 3.62 and $3.60 \mathrm{tha}$ 1 , respectively. Boron gives the highest wheat grain yield due to maximum number of grains spike $^{-1}$ while $\mathrm{Cu}$ and $\mathrm{Mn}$ increased the number of tillers. Kumar et al. (2009) recorded 68\% yield increase over control with the application of $\mathrm{Cu}$. (Ali, 2012; Tahir et al., 2009; Khan et al., 2010; Nadim et al., 2012; Raza et al., 2014), observed that the grain yield of wheat can be increased by application of $\mathrm{Fe}$ and $\mathrm{B}$ alone or combined with other micronutrients. Ma et al. (2017) conducted experiment to observe the physiological responses of wheat to $\mathrm{Zn}$ fertilizer application under drought stress, pot, and field experiment under different soil moistures and treated with soil and foliar $\mathrm{Zn}$ applications. $\mathrm{Zn}$ application in soil significantly increased grain yield of wheat and $\mathrm{Zn}$ concentration by 10.5 and $15.8 \%, 22.6$ and $9.7 \%$, and 28.2 and $32.8 \%$ under adequate water supply, moderate drought, and severe drought, respectively. Zinc directly alleviates wheat plant drought stress by $\mathrm{Zn}$ -mediated increase in photosynthesis pigment and active oxygen scavenging substances, and reduction in lipid peroxidation.

Plant height (cm): Zain et al. (2015) showed that foliar application of $\left(\mathrm{FeSO}_{4}+\mathrm{MnSO}_{4}\right)$ gives increased maximum plant height $(97.00 \mathrm{~cm})$ that was statistically similar to (FeSO4 $+\mathrm{ZnSO} 4)$, ( $\mathrm{ZnSO} 4+\mathrm{MnSO} 4)$ and (FeSO4+ZnSO4+MnSO4). Single dose of (3 kg ZnSO4) gives minimum plant height $(85.567 \mathrm{~cm})$. Khan et al. (2009) showed that plant height increase up to $5.8 \%$ if treated with ZnSO4 (10 kg ha-1) as compared to untreated 
wheat. Rawashdeh et al. (2015) observed that the plant height of wheat increased significantly $(p=0.05)$ due to foliar application of micronutrient ( $\mathrm{Fe}, \mathrm{B}, \mathrm{Fe}+\mathrm{B}$ ) at individual stages (at 21 days or 41 days) and at both stages (at $21+41$ days). The highest plant height observed $14.00 \%$ by application of $333 \mathrm{~g} \mathrm{Fe} \mathrm{ha}^{-1}+167 \mathrm{~g} \mathrm{~B}^{-1}$ (at $21+41$ days) followed by $12.33 \%$ and $11.20 \%$ by $333 \mathrm{~g} \mathrm{Fe} \mathrm{ha}^{-1}$ (at 21+41days), and $333 \mathrm{~g} \mathrm{Fe} \mathrm{ha}^{-1}+167 \mathrm{~g} \mathrm{~B} \mathrm{ha}^{-1}$ (at 21 days), respectively over control. This is due to Fe play an important role in chlorophyll synthesis, energy transfer and enters in root cells and $B$ having role in physiological processes i.e. cell elongation, cell maturation, meristematic tissue development, sugar transportation, IAA, formation, germination and protein synthesis etc. Similar results obtained that plant height of wheat increased due to foliar application of micronutrient (Ali, 2012; Bameri et al., 2012; Rehman et al., 2012; Rawashdeh and Sala, 2013a). Kandoliya et al. (2018) recorded highest grain and straw yield of wheat under the application of RDF (Recommended dose of fertilizer) + soil application of ZnSO4 (10 kg ha-1) + FeSO4 (20 kg ha $\left.{ }^{-1}\right)$. Under same treatment the yield attributes such as plant height at 40 DAS, 70 DAS and at harvest; numbers of tillers at 45 DAS and at harvest and numbers of effective tillers at harvest of wheat crop were recorded significantly highest.

Flag leaf area: Rawashdeh et al. (2015) showed that flag leaf area of wheat significantly increased $(p=0.05)$ by application of (foliar) of micronutrient ( $\mathrm{Fe}, \mathrm{B}$ and $\mathrm{Fe}+\mathrm{B}$ ) at individual stages (at 21 days or 41 days) and at both stages (at 21+41 days). The maximum flag leaf area reported that $39.13 \%$ by application of $333 \mathrm{~g} \mathrm{Fe} \mathrm{ha}^{-1}+167 \mathrm{~g} \mathrm{~B} \mathrm{ha}^{-1}$ (at $21+41$ days) followed by $27.57 \%, 22.43 \%$ and $19.13 \%$ by $333 \mathrm{~g} \mathrm{Fe} \mathrm{ha}^{-1}$ (at $21+41$ days), $167 \mathrm{~g} \mathrm{~B}$ $\mathrm{ha}^{-1}$ (at 21+41days), and $333 \mathrm{~g} \mathrm{Fe} \mathrm{ha}^{-1}+167 \mathrm{~g} \mathrm{~B}$ ha $^{-1}$ (at 41 days), respectively over control. Because of $\mathrm{Fe}$ is an important component of cytochrome which involved in electron transport chain (ETS), chlorophyll sysnthesis, maintain structure of chloroplasts, nitrogen fixation and enzymatic activities (Eskandari, 2011) which lead to higher crop production and leaf area increase (Zayed et al., 2011).

Chlorophyll content: Rawashdeh et al. (2015) reported that foliar application of micronutrient ( $\mathrm{Fe}, \mathrm{B}$ and $\mathrm{Fe}+\mathrm{B}$ ) at individual stages of wheat (at 21 days or 41 days) and at both stages (at $21+41$ days) increase in chlorophyll content of plant leaves. The highest chlorophyll content of plant leaves obtained that $18.96 \%$ by application of $333 \mathrm{~g} \mathrm{Fe} \mathrm{ha}{ }^{-1}+167 \mathrm{~g} \mathrm{~B} \mathrm{ha}{ }^{-1}$ (at $21+41$ days) followed by $16.22 \%, 12.40 \%$ and $12.07 \%$ by $333 \mathrm{~g}$ $\mathrm{Fe} \mathrm{ha}^{-1}$ (at 21+41days), $333 \mathrm{~g} \mathrm{Fe} \mathrm{ha}^{-1}$ (at 41days), and $333 \mathrm{~g} \mathrm{Fe} \mathrm{ha}{ }^{-1}+167 \mathrm{~g} \mathrm{~B} \mathrm{ha}^{-1}$ (at 41 days), respectively over control. Similar results reported by (Kazemi, 2013; Rawashdeh and Sala, 2014b) observed that application of $\mathrm{Fe}$ and $\mathrm{B}$ alone or in combined with other micronutrients increased chlorophyll content of plants leaves. Jat et al. (2018) also reported that, the application of zinc (3 $\mathrm{kg} \mathrm{ha}^{-1}$ ) increased the biosynthesis of important growth hormones i.e. indole acetic acid (IAA) which is responsible for wheat plant growth, resulted in increased plant height or plant growth. It was also observed the higher amount of chlorophyll content in a treatment of $\mathrm{Zn}$ and $\mathrm{Fe}$ (Sale et al., 2018; Kandoliya et al., 2018). Thus increase in photosynthetic process, resulting increase in the growth of wheat plants.

Micronutrients concentration in flag leaves and grains ( $\boldsymbol{~ g ~ g ~ g}^{-1}$ ): Rawashdeh et al. (2015) reported that the highest concentration of micronutrients ( $\mathrm{Fe}, \mathrm{B}, \mathrm{Zn}$ and $\mathrm{Cu}$ ) in flag leaves and grains of wheat were obtained by application of $333 \mathrm{~g} \mathrm{Fe}$ $\mathrm{ha}^{-1}+167 \mathrm{~g} \mathrm{~B} \mathrm{ha}^{-1}$ (at $21+41$ days). This results was supported by (Zeidan et al., 2010; Gomaa et al., 2015) that foliar application of micronutrients substantially increased concentration of micronutrients in flag leaves and grains.

Biological yield (kg/ha): Zain et al. (2015) found maximum biological yield of wheat by application of ( $\mathrm{ZnSO} 4+\mathrm{MnSO} 4)$ followed by (FeSO $4+$ ZnSO4) treatment. Also found that significant positive correlation between micronutrient and dry matter production. Yadav et al. (2017) conducted the field experiment during the rabi season found that Zn application @10 kg ha ${ }^{-1}$ significantly improved all growth parameters and yield attributes of wheat crop over the control. Zinc plays an important role in regulating the auxin concentration in plant and nitrogen metabolism in wheat crop and improved in these growth attributes. Similar results were reported by Hrivna et al., (2015) and Noonari et al. (2016).

Harvest Index (\%): Ratio of yield over biomass called Harvest index. Zain et al. (2015) reported that application of (FeSO4 $+\mathrm{ZnSO} 4+\mathrm{MnSO} 4)$ produced maximum harvest index (42.263) of wheat which was statistically at par with (FeSO4 + MnSO4) treatment. Also Webb and Loneragan (1990) found that significant positive relationship between the micronutrient and biomass production of wheat.

Rani et al. (2019) showed that application of micronutrient such as $\mathrm{Mn}, \mathrm{Zn}$ and $\mathrm{Fe}$ alone or in a combination of manganese and iron significantly increased yield and yield attributes of wheat. The application of $\mathrm{Zn}$ increases, the concentration of $\mathrm{Zn}$ in the shoots and grains of wheat increases significantly. Grain protein content was decreased by salinity, while the utilization of grain protein enhanced and finally improved the growth and yield of wheat by decreasing the effects of salinity, therefore the addition of $\mathrm{Zn}$ helped in reducing the unfavorable effects.

Now a days to meet the feed of global population, 
there is a demand of high yielding crops. To increase the yield production of wheat crop we are using high analysis NPK fertilizers which contain low amount of micronutrients. High yielding results in removing the micronutrients from the soil. Also the advances in fertilizer technology reduce the residual addition of micronutrients. So there is need of balanced nutrition for soil to crop which meets the demands of soils, crops as well as human health.

Micronutrients promote the good, strong and steady growth of plants that produce higher yields and increase the harvest of produce. Balanced application of micronutrient application will significantly improve the yield attributes of wheat crop such as leaf area index (LAI), leaf area duration, crop growth rate, net assimilation rate, relative growth rate plant height, spike length, spikelet's/ spike, grains/spike, test weight, tillers $\mathrm{m}^{-2}$, grain yield, chlorophyll content, biological yield as well as harvest index etc.

\section{Conclusion}

A balanced use of macronutrients with micronutrients fertilization is very important for high yield crops and good quality products as well as plant nutrition. Micronutrients play a significant role in chlorophyll synthesis, nucleic acid, protein synthesis and formation, different enzymatic activities, photosynthesis as well as respiration. The balance use fertilization also improves yield and quality of crop by application of micronutrient alone or combined forms give better results over control. The Result have show that micronutrient application substantially improve leaf area index (LAl), leaf area duration, crop growth rate, net assimilation rate, relative growth rate, plant height, spike length, spikelet's/spike, grains/spike, test weight, tillers $\mathrm{m}^{-2}$, grain yield, chlorophyll content and biological yield as well as harvest index of wheat. This study will be helpful for farmers and human welfare in understanding the stages of growth, right micronutrients time, dose, and helped the plants grow successfully under unfavorable conditions.

\section{REFERENCES}

1. Abbas, G., Khan, M. Q., Jamil, M., Tahir, M. and Hussain, F. (2009). Nutrient uptake, growth and yield of wheat (Triticum aestivum L.) as affected by zinc application rates. International Journal of Agriculture and Biology 11: 389-396.

2. Ali, E. A. (2012). Effect of iron nutrient care sprayed on foliage at different physiological growth stages on yield and quality of some durum wheat (Triticum durum I.) varieties in sandy soil. Asian J. of Crop Sci. 4 (4): 139-149.

3. Ali, S., Shah, A., Arif, M., Miraj, G., Ali, I., Sajjad, M., Farhatullah, Khan, M. Y. and Khan, N. M. (2009). Enhancement of wheat grain yield and yield components through foliar application of Zinc and Boron. Sarhad J. Agric. 25(1): 15-19.
4. Asad, A. and Rafique, R. (2002). Identification of micronutrient deficiency of wheat in the Peshawar valley. Commun. Soil Sci. Plant Anal. 33: 349-364.

5. Bameri, M., Abdolshahi, R., Mohammadi-Nejad, G., Yousefi, K. and Tabatabaie, S. M. (2012). Effect of different microelement treatment on wheat (Triticum aestivum) growth and yield. Intl. Res. J. Appl. Basic. Sci. 3(1): 219-223.

6. Blevins, D. G. and Lukaszewski, K. M. (1998). Boron in plant structure and function. Annual Review of Plant Physiology and Plant Molecular Biolog, 49: 481 -500 . annurev.arplant.49.1.481

7. Cakmak, I. (2000). Possible roles of zinc in protecting plant cells from damage by reactive oxygen species. New Phytol. 146: 185-205.

8. Cakmak, I. (2008). Enrichment of cereal grains with zinc: Agronomic or genetic biofortification?. Plant Soil 302: 1-17.

9. Card, S., Cathcart, J. and Huang, J. (2005). The micronutrient and trace element status of crops grown on the Alberta Soil Quality Benchmark Sites. AESA Soil Quality Monitoring Program, Alberta Agri. Food \& Rural Dev., Cons. \& Dev. Branch, pp.20.

10.Chaudry, E. H., Timmer, V., Javed, A. S. and Siddique, M. T. (2007). Wheat response to micronutrients in rainfed areasof Punjab. Soil \& Environ. 26: 97 $-101$.

11. Ducic, T. and Polle, A. (2005). Transport and detoxification of manganese and copper in plants. Braz. J. Plant Physiol. 17: 103-112.

12.Eskandari, H. (2011). The importance of iron (Fe) in plant Products and Mechanism of Its uptake by plants. J. Appl. Environ. Biol. Sci. 1(10): 448-452.

13.Fageria, N. K. (2007). Soil fertility and plant nutrition research under field conditions: Basic principles and methodology. Journal of Plant Nutrition 30(2): 203223.

14.Gomaa, M. A., Radwan, F. I., Kandil, E. E., ElZweek, S. M. A. (2015). Effect of some macro and micronutrients application methods on productivity and quality of Wheat (Triticum aestivum L.). Middle East J. Agric. Res. 4(1): 1-11.

15. Hrivna, L., Kotkova, B. and Buresova, I. (2015). Effect of sulphur fertilization on yield and quality of wheat grain. Food Science and Technology Abstracts Cereal Research Communications. 43(2): 344-352.

16.Islam, M. R., Islam, M. S., Jahirhuddin, M. and Hoque, M. S. (1999). Effect of sulphur, zinc and boron on yield, yield components and nutrients uptake of wheat. Pakistan Journal of Science and Industrial Research, 42: 137-140.

17.Jat, R. C., Sharma, Y., Jakhar, R. K. and Sharma, R. K. (2018). Effect of phosphorus, zinc and iron on yield and quality of wheat in western Rajasthan, India. Int. J Curr. Microbiol. App. Sci., 7(3): 2055-2062.

18.Kandoliya, R. U., Sakarvadia, H. L. and Kunjadia, B. B. (2018). Effect of zinc and iron application on leaf chlorophyll, carotenoid, grain yield and quality of wheat in calcareous soil of Saurashtra region. International Journal of Chemical Studies, 6(4): 20922095.

19.Kandoliya, R. U., Talaviya, B. P. and Kunjadia, B.B. (2018). Effect soil and foliar application of zinc and iron on growth of wheat plant in calcareous soil of Saurashtra region. European Journal of Biotechnology and Bioscience, 6(5): 86-90. 
20.Kaya, C. and Higgs, D. (2002). Response of tomato (Lycopersicon esculentum L.) cultivars to foliar application of zinc when grown in sand culture at low zinc. Sci. Hortic. 93: 53-64.

21.Kazemi, M. (2013). Effect of Foliar Application of Iron and Zinc on Growth and Productivity of Cucumber. Bull. Env. Pharmacol. Life Sci., 2(11): 11-14.

22.Khan, H. R., McDonald, G. K. and Rengel, Z. (2003). $Z n$ fertilization improves water use efficiency, grain yield and seed $\mathrm{Zn}$ content in chickpea. Plant Soil, 249: 389-400

23.Khan, R., Gurmani, A. R., Khan, M. S. and Gurmani, A. H. (2007). Effect of zinc application on rice yield under wheat rice system. Pakistan Journal of Biological Sciences, 10: 235-239. http://dx.doi.org/10.3923/ pjbs.2007.235.239

24.Khan, R., Gurmani, A. R., Khan, M. S. and Gurmani, A. H. (2009). Residual, direct and cumulative effect of zinc application on wheat and rice yield under ricewheat system. Soil and Environment 28: 24-28.

25.Khan, S., Mirza, K. J., Anwar, F. and Abdin, M. Z. (2010). Development of RAPD markers for authentication of Piper nigrum. Environment \& International Journal of Science and Technology, 5: 53-62.

26.Kumar, R., Mehrotra, N. K., Nautiyal, B. D., Kumar, P. and Singh, P. K. (2009). Effect of copper on growth, yield and concentration of $\mathrm{Fe}, \mathrm{Mn}, \mathrm{Zn}$ and $\mathrm{Cu}$ in wheat plants (Triticum aestivum L.). J. Environ. Biol., 30: 485-488.

27.Liew, C. S. (1988). Foliar Fertilizers from Uniroyal and their Potential in Pakistan. Proceedings of Seminar on Micronutrient in Soils and Crops in Pak, 277 (Abstract)

28.Ma, D., Sun, D., Wang, C., Ding, H., Qin, H., Hou, J., Huang, X., Xie, Y. and Guo, T. (2017). Physiological responses and yield of wheat plants in zinc-mediated alleviation of drought stress. Frontiers in Plant Science, 8:1-12. doi: $10.3389 /$ fpls. 2017.00860 .

29.Manal, F. M., Thalooth, A. T. and Khalifa, R. K. M. (2010). Effect of foliar spraying with uniconazole and micronutrients on yield and nutrients uptake of wheat plants grown under saline condition. J. Amer. Sci,. 6 : 398-404.

30.Mandal, A., Patra, A. K., Singh, D., Swarup, A. and Masto, R. E. (2007). Effect of long-term application of manure and fertilizer on biological and biochemical activities in soil during crop development stages. Bioresour. Technol., 98: 3585-3592.

31.Maralian, H. (2009). Effect of Foliar Application of Zn and $\mathrm{Fe}$ on Wheat Yield and Quality. African Journal of Biotechnology, 8: 6795-6798.

32.Modaihsh, A. S. (1997). Foliar application of chelated and non-chelated metals for supplying micronutrients to wheat grown calcareous soils. Experimental Agriculture 33: 237-245. http:// dx.doi.org/10.1017/S001447979700001X

33.Moghadam, M. J., Sharifabad, H. H., Noormohamadi, G., Sadeghian Motahar, Y. and Siadat, S. A. (2012). The Effect of Zinc, Boron and Copper Foliar Application, on Yield and Yield Components in Wheat (Triticum aestivum L.). Ann. Biolo. Res., 3(8): 3875-3884

34.Nadim, M, A., Awan, I. U., Baloch, M. S., Khan, E. A., Naveed, K., Khan, M. A., Zubair, M. and Hussain, N. (2011). Effect of micronutrients on growth and yield of wheat. Pak. J. Agri. Sci., 48(3): 191-196.

35.Nadim, M. A., Awan, I. U., Baloch, M. S., Khan, E.
A., Naveed, K., Khan, M. A. (2012). Response of wheat (Triticum aestivum L.) to different micronutrients and their application methods. J. Anim. Plant Sci. 22(1): 113-119.

36.Nataraja, T. H., Halepyati, A. S., Pujari, B. T. and Desai, B. K. (2006). Influence of phosphorus levels and micronutrients on the physiological parameters of wheat. Karnataka J. Agri. Sci. 19: 685-687.

37.Noonari, S., Kalhoro, S. A., Ali, A. Mahar, A. Raza, A. Ahmed, M. Shah, S. F. A. and Baloch, S. U. (2016). Effect of Different Levels of Phosphorus and Method of Application on the Growth and Yield of Wheat. Natural Science, 8: 305-314.

38.Rani, S., Sharma, M. K., Kumar, N. and Neelam (2019). Impact of salinity and zinc application on growth, physiological and yield traits in wheaT. Current science 116(8): 1324-1330. DOI: 10.18520/cs/ v116/i8/1324-1330.

39.Rawashdeh, H. and Sala, F. (2013). Effect of different levels of boron and iron foliar application on growth parameters of wheat seedlings. African Crop Science Conference Proceedings, 11: 861-864.

40.Rawashdeh, H. and Sala, F. (2013). Effect of different levels of boron and iron foliar application on growth parameters of wheat seedlings. African Crop Science Conference Proceedings, 11: 861-864.

41.Rawashdeh, H. and Sala, F. (2015). Effect of some micronutrients on growth and yield of wheat and its leaves and grain content of iron and boron. Bulletin USAMV series Agriculture, 72(2).

42.Rawashdeh, H. M. and Sala, F. (2013). The effect of foliar application of iron and boron on early growth parameters of wheat (Triticum aestivum L.). $R e$ search Journal of Agricultural Science, 45(1): 21-26.

43.Raza, S. A., Ali, S., Chahill, Z. S., Iqbal, R. M. (2014). Response of foliar application of boron on wheat (Triticum aestivum L) crop in calcareous soils of Pakistan. Acad. J. Agric. Res., 2(3): 106-109.

44.Reddy, S. R. (2004). Principles of crop production growth regulators and growth analysis, 2 nd ed. kalyani publishers, Ludhiana, india.

45.Rehm, G. and Albert, S. (2006). Micronutrients and Production of Hard Red Spring Wheat. Minnesota Crop e News, 7: 1-3.

46.Rehman, S. U., Hussain, N., Tariq, M., Hussain, M., Nasir, M., Ayaz, M. (2012). Response of wheat to exogenous boron supply at various growth stages. Sarhad J. Agric., 28(3): 411-414.

47.Saeed, B., Gul, H., Khan, A. Z., Badshah, N. L., Parveen, L. and Khan, A. (2012). Rates and methods of nitrogen and sulfur application influence and cost benefit analysis of wheat. Journal of Agricultural \& Biological Science 7(2): 81-85.

48.Sale, R. B., Nazirkar, R. B., Thakare, R. S. and Kondvilkar, N. B. (2018). Effect of foliar spray of zinc, iron and seed priming with molybdenum on growth and yield attributes and quality of soybean in the rainfed condition of Vertisol. Int. J of Chemical Studies 6(1): 828-831.

49.Shukla, S. K. and Warsi, A. S. (2000). Effect of sulphur and micronutrients on growth, nutrient content and yield of wheat (Triticum aestivum L.). Indian J. Agri. Res. 34:203-205.

50.Suleimani, R. (2006). The effects of integrated application of micronutrient on wheat in low organic carbon conditions of alkaline soils of Western Iran. Proc. $18^{\text {th }}$ World Congress of Soil Sci. Philadelphia, USA. 
Louhar, G. et al. / J. Appl. \& Nat. Sci. 11(4): 823 - 829 (2019)

51.Sultana, N., Ikeda, T. and Kashem, M. A. (2001). Effect of foliar spray of nutrient solutions on photosynthesis, dry matter accumulation and yield in seawater-stressed rice. Environ. Exp. Bot. 46: 129-140.

52.Sultana, S., Naser, H. M., Shil, N. C., Akhter, S. and Begum, R. A. (2016). Effect of foliar application of zinc on yield of wheat grown by avoiding irrigation at different growth stages. Bangladesh J. Agril. Res. 41 (2): 323-334.

53.Tahir, M., Tanveer, A., Shah, T. H., Fiaz, N. and Wasaya, A. (2009). Yield response of wheat (Triticum aestivum L.) to boron application at different growth stages. Pak. J. Life Soc. Sci. 7: 39-42.

54.Uddin, M. N., Islam, M. S. and Islam, A. B. M. S. (2008). Effect of boron on wheat at different boron application methods. J. Subtrop. Agric. Res. Dev. 6: 483-486.

55.Webb, M. J. and Loneragan, J. F. (1990). Zinc translocation to wheat roots and its implications for a phosphorus/zinc interaction in wheat plants. Journal of Plant Nutrition 13: 1499-1512. http:// dx.doi.org/10.1080/01904169009364171

56.Yadav, S. K., Singh, G., Kumar, R., Kumar, P. and Mohan, B. (2017). Effect of Phosphorus, Sulphur and Zinc on Growth, Yield and Yield Attributes of Wheat (Triticum aestivum). Int. J. Curr. Microbiol. App. Sci.
6(8): 2581-2584. https://doi.org/10.20546/ijcmas.2 017.608.306.

57.Zain, M., Khan, I., Qadri, R. W. K., Ashraf, U., Hussain, S., Minhas, S., Siddique, A., Jahangir, M. M. and Bashir, M. (2015). Foliar application of micronutrients enhances wheat growth, yield and related attributes. American Journal of Plant Sciences, 6: 864-869.

58.Zayed, B. A., Salem, A. K. M. and Sharkawy, H. M. (2011). Effect of different micronutrient treatments on rice (Oriza sativa L.) growth and yield under saline soil conditions. World J. Agric. Sci. 7(2): 179-184.

59.Zeidan, M. S., Manal, F. and Hamouda, H. A. (2010). Effect of foliar fertilization of $\mathrm{Fe}, \mathrm{Mn}$ and $\mathrm{Zn}$ on wheat yield and quality in low sandy soils fertility. World $J$ Agric Sci. 6(6): 696-699.

60.Ziaeian, A. H. and Malakouti, M. J. (2001). Effect of micronutrient application on wheat production in calcareous soils. Prepared for the Second National Conference on Optimum Utilization of Chemical Fertilizers and Pesticide in Agriculture, Karaj, Iran.

61.Ziaeian, A. H. and Malakouti, M. J. (2001). Effects of $\mathrm{Fe}, \mathrm{Mn}, \mathrm{Zn}$ and $\mathrm{Cu}$ fertilization on the yield and grain quality of wheat in the calcareous soils of Iran. Food Security and Sustainability of Agro-Ecosystems, pp.840-841. 